\title{
Echo w służbie poezji rokoszu Zebrzydowskiego
}

Urszula Wich 


\section{Urszula Wich}

\section{Echo w służbie poezji rokoszu Zebrzydowskiego}

W azwa omawianego gatınku literatury okolicznościowej wywodzi się od greckiego stosus echori) odnajdywane sa już w poezji antycznej. Wspomina o nich Marcjalis (Epigrammata II 86). W III w. 11. e. pisal utwory echowe poeta Pentadiusz, układając je w dystychach elegijnych!'.

Istotę echa stanowi wykorzystanie w funkcji elementu struktury literackiej znanego zjiwiska akustycznego: powtórzenia glosu odbitego od przeszkody. W wierszach tę ,przeszkodę" stanowilo odpowiednic usytuowanie wyrazów rymującyclı się. Poezja staropolska rymowala najczesściej pary wersowe, powtarzaja jednakowe lub podobne brzmienia akcentowanych części wyrazów w klauzuli wicrsza. W echu rymowa para stoi obok siebic, przy czym ów echowy rym bywa - najczęściej - pod względem zasobu zgloskowego cząsthą wyrazu, z którym siç rymuje (cząstką samodzielıą znaczeniowo).

Literatura barokowa uprawiala i drugi rodzaj echa. Tı wyrazy rynowe staly obok siebie, ale rym echowy nie byl cząstką wyrazı poprzedzajłacego. Ten rodzaj echa występowat w poezji politycznej i satyrycznej; pełnil on - jak się zdaje — finıkcje perswazyjne, silnicj dzialal na odbiorcę. Oba rodzaje echa zachowywaly też rygorystycznie konstrukcję rozmowy; echo bylo odpowiedzią na postawione pytanie, odpowiedzią przewrotną, ironiczną lub satyrycznąㄹ. W toku obecnych poszukiwań, dla celów tej pracy znaleziono także trzeci rodzaj echa, mianowicie jest to taka konstrukcja wierszowa, w którym echo odpowiada calym zdaniem. Wszystkie trzy wymienione warianty echa świadczą o tym, ze w dobie baroku mamy do czynienia z gatunkiem poezji konceptystycznej, w którym element ludyczny ma znaczenie pierwszo-

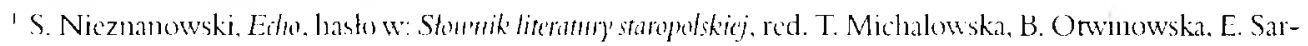
nowska-Temeriusz. Wroclaw 1948, s. 182-183.

zllidem.s. 182. 
planowe, i zostal calkowicic podporządkowany wydobyciu i wyakcentowaniu polemicznego charakteru wiersza.

Bardzo trudno badaczom ustalić dokładną datę pojawienia się tego gatunku w Polsce. Z dostępnych źródel wiadomo, że na większą skalę używali go poeci okresu pierwszego bezkrólewia, twórcy „przedelekcyjni” (po śmierci Stefana Batorego) i poeci doby rokoszu Zebrzydowskiego (1606-1608); odtąd odnajdywać będzienny tego typu wiersze w różnych tematycznie dzialach poezji. W okolicznościowej poezji politycznej echo było dobrym sposobem kompromitacji przeciwników, ụawniato ich podstępność, złe zamiary, niemoralność. Chroniło sojusznikow ideowych autora, wzbudzając sympatię odbiorcy, spetnialo wreszcie tak istotny dla poezji barokowej postulat konceptystycznej pointy, z wykorzystaniem gier słownych, zaskakujących zmian sensów.

Częstsza w tym dziale poezji była druga forma echa. Budowa tych utworów wymagała, aby wykorzystać brzmienia bliskie, ale niebędące cząstką wyrazu rymowanego. Replikı Echa stanowią cale wyrazy, zbliżone brzmieniowo do klauzuli wersu, któremu Echo odpowiada, zawieraja zaś cięte, złośliwe, ironiczne, satyryczne jedno- lub dwuwyrazowe oceny omawianych wydarzeń, ujęte niesłychanie zręcznie, inteligentnie, świadczące o wirtıozerii warsztatowej autora wiersza. Tego typu wiersze w walce politycznej, jak widać, były przydatniejsze, zaskakiwały czytelnika zorientowanego w regułach gatunkowych oryginalną kompozycja, podsuwaly nu rozwiązania niespodziewane, jak np. Edıo rokoszaniskic (1606). Ów polityczny wiersz o budowie echa, pióra autora-anonima, reprezentuje oczywiście omawianą, znaną przecicz dobrze sztuczkę literackį i praktykowaną w literaturze czasów zygmuntowskich. Twórca stanął przed trudnym wyzwaniem artystycznym, chcąc przy pomocy skromnego echa sprostać zadaniu opisania skomplikowanej rzeczywistości politycznej, celnie. krótko. z akcentami satyrycznymi charakteryzując calą galerię polityków i stronnictw politycznych:

\section{Echo rokoszańskie}

Ehcj ccho, wszak się tı głos ludzi odbija? - Mija.

Różne tu wieści niosą ci, co przemijają? - Tają.

Czemu tają? Wszak wszytkim wszytko jest wiadomo? - Rzekomo.

Ja pytam, tu odpowiedz, a stow nie podchwytaj! - Pytaj!

Co to za konkurs ludzi, w Sandomierzu ich kosz? - Rokosz.

To tam róg z królem będzie, odkryją zle rady? — Zdrady.

Będą tam chcieć podźwignąc swych wolności calc? - Alc.

Abo król kazil wolność i swobody nasze? - Zawsze.

$Z$ cicha snać ingum wnosil fortelnie, nie hucznie? - Sztucznie.

A prawdaz to, że z Niemcy o nas praktykowat? - Knowat.

I choć nwierdzą, że nieraz przysięgę nam zlamał? - Skłamał.

Jakoż to się stać noglo, wszak miał wiermą radę? - Zdradę.

A wiedzieliz też o tym dworscy kamerarze? - Egarze.

Snać o tym Jezuici cicho praktykują? - Knują. 
Skarga-ć w glos w swych kazaniach o tym retoruje? - Psuje.

Czegoż ta pestis godna zdrajcy. Jezuici? - Wici.

Tak bym je radzil karać, jako Wenceyja? - I ja.

Trzeba by zdrajce przepleć i uczynić w nich brak? - Ej, tak!

I pany rady, zdrajce, przyjdzie karać za tem? - Katem.

Bobola azaż tego panu nie rozradza? - Zdradza.

Więc pod miecz wszytki zdrajce, a naprzód Bobolę? - Wolę.

A dalej czego czekać po tym milym królu? - Bólu.

Non regnabis nie rzeknąc cnotliwi panowie? - Kto wię.

Lepiej by mu rozkazać: Unykaj sic̨ z Polski! — Z wojski.

Alias w takich zdradach królestwo upadnie. - Snadnie.

Z takimić trudno wskórać rzeczypospolitej. - I tej.

To nic ujdą karania, którzy są w Wiślicy? - I ci.

Gonzaga przedni zdrajca, nie wychodzi z gmachu. - Z strachu.

Gostomski wojewoda wżdyć to dobry rajca? - Zdrajca.

Wojewoda podlaski to senator prawy? - Z strawy.

Aleć tak twierdzą drudzy, że senator godny. — Glodny.

Sieradzki wojewoda, slyszę, się odmienil? — Zmienil.

Gulski, to z sowy sokót, niewysoko buja. - Szuja.

Ostrorog pan poznaniski, zda się być w radzie brant? - Frant.

I hetman polny przed tym coś lepszego radzil? - Zdradził.

Wżdyć się przeciw królowi z ślachtą opowiedil? - Przedał.

A inszy senatorowie, wolniz tej pokusy? - Prusy.

Bo tak ci, wierę̧, slychać, żoć się zaprzedali. - Brali.

Lubomirski, czego też z swoim synkiem szuka? - Czeka.

Slachta ta, co przy królu. są tam ludzie godni? - Glodui.

Wżdyć też i ci szukają ojczyźnie dobrego? - Swego.

To zdrajcy tanci ślachıta i nadworni słudzy? - Drudzy.

Obietnice tam drugich, tak tuszę, zawiodly? - Zwiodly.

Co mówisz? Wszak król takim, co obieca, rad da? - Przeda.

O księzzj, co rozmmiesz, przy wolnościach stoją? - Broją.

Ze z ślachtą, a nie z królem przeciwnym przestają? - Lają.

Ci mieli być dobrego wierni wynalazcy? - Skaźscy.

O kole rokoszowym niech tez twe zdanic wiem. - Powiem.

Pan krakowski nie z nimi, bo to pan niechudy? - Dudy.

Przestrzega wolności i powagi pana? - Dzbana.

Co mówisz, zawżdyć ten pan inalpate zyje? - Pije.

Wojewoda krakowski czlek nicpospolity? - Skryty.

Przy wolnościach jest staly w rzeczypospolitej? - Przy tcj.

Mieszka w nim on animusz kanclerza mądrego? - Tego.

To podobıo dla tego król w nim nie ma smaku? - Znaku.

Bracławski co z wołyńskim ci wojewodowie? - Kpowie. 
Nuż wojewoda rawski co ma za przymioty? - Cnoty.

A radzi, czy wet za wet oddawa sowito? - I to, i to.

Pan wiślicki z czechowskim, słyszę, z sobą tchórzą? - Trwożą.

Pan parnawski z żarnowskim, i ci nic zawadzą? - Radzą.

Marszałek z Litwy stanąl ojczyzny przy boku? - W kroku.

A Radziwill podczaszy dźwigaż rzecz potężnie? - Mężnie.

Podziçkowania za to, wierę, godzien będzie? - Wszędzie.

Pan też Krzysztof, brat jego, i ten staną̧ w sprawie? - Prawie.

Powiedają, ze przybył prawie okazale? - Ale.

Więc pan trocki, Radziwill, piękne wojsko stawił? - Sprawił.

Tó́ wszyscy z kosztem pragnia ojczyzny dobrego? - Tego.

Opocznianie szeregiem rządıi i potężni? - Grzeczni'.

Stadnicki, jak lew głodny, resolut potężny? - Mężny.

Prawdaź to, że w Wiślicy na garło mu stoją? - Boją.

Easzcz za nim tuz z Polaki i z mężną postawą? - Sprawą.

Gorajski ich nie wyda, bo i ten jest twardy? - Hardy.

Urowicki z bulawą wąsami potrząsa? - Kąsa.

A wszakże on w sąsiedztwie z każdym dobrze żyje? - Bije.

Krzysztof Sieniński idzie z sercem i z ochotą? - Z rotą.

A pan Jakub, brat jego, miłujeż jeszcze bój? - Pokój.

Z lekki idzie, [a] w rzeczach szczerze postępuje? - Czuje.

Pan podkomorzy chehnski żohnierz to, czyli żak? - Zmindak.

I lerbort chorąży w radzic jako olej plynie? - Stynie.

Broniowski z industryją i z gladką wymową? - Glowa.

Pękoslawski milośnik prawic swobód caly? - Stały.

Wołyńscy nicbożęta czemuż się wahali? - Bali.

To są w jarzmie niewoli kniazia Zbarawskiego? - Tego.

Inszy przecie tak w radach, jak do boju czyści? - Wszyscy.

Umawialiż siç z tobą w radach swych łagodnie? - Zgodnie.

Za wolność unrzeć cliçtniz, o pobór nie łają? - Daja.

Już cię żegnam, bądź łaskaw, a trwaj przy tym stale. — Iale! ${ }^{+}$

Zakończenie tegoż utwon jest makaronizujące, wyraz polski rymuje się z lacińskim, typowym zwrotem pożegnalnym lále! - „Zegnaj!”, tutaj sygnalizującym także koniec wiersza. W utworze tym, ulożonym w formie dysputy, wyraźny jest nadawca i odbiorca.

\footnotetext{
'Odpowiedź Echa jest tu chyba znicksztalcona przez kopistę, bo nic rymuje siç z wyrazem poprzedzajacym,

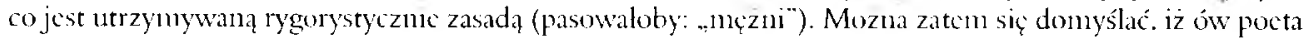
pochodzil z Opoczyńskiego.

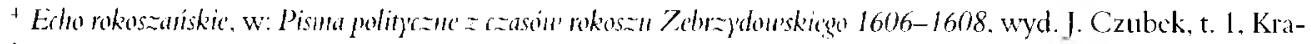
ków 1916, s. 85-87.
} 
Wydaje siç, ze ów autor-anonim ${ }^{5}$ wyszedł z tego trudnego zadania (przedstawienia skomplikowanej rzeczywistości politycznej) na ogól z powodzeniem, udaje mu siç harmonijnie pod względem artystycznym pokazać całość bardzo bogatego faktograficznie obrazı politycznego. W kolejnych osiemdziesięciu pięciu wersach swego utworu zdołał ukazać galerię kilkudziesięciu przedstawicieli obu obozów polityczuych. głównie królewskiego, przydzielając kazdej osobie jeden, najwyżej dwa wiersze tekstu.

W utworze tym pojawia się rzesza znanych osobistości świata polityki: Piotr Skarga, Andrzej Bobola, lırabia Zygmunt Gonzaga Myszkowski, Anzeln Gostomski, hetman polny Stanisław Zólkiewski i kasztelan krakowski Janusz Ostrogski. Wymienione postaci oczywiście przedstawione sạ w negatywnym świetle, szczególnie zaś hetman polny i kasztelan krakowski, którzy to dość późnym zdeklarowaniem się po stronie królewskiej wywolali zrazı uczucie nadziei w obozic rokoszańskim, potem - wiçkszego zawodı i g gniewu.

Odpowiedzi Echa zawierają ironiczne lub satyryczne, a zawsze krytyczne repliki na opinie zawarte w poszczególnych wersach. Twörcal wiersza jest doskonale zorientowany w sytıacji wewnętrzıej Rzeczypospolitej, ciętał, zjadliwą satyrą posłıgıje się przy charakteryzowanin uczestników rokoszu i stronnictwa królewskiego. Określenia sa trafne, zlośliwe, nie oszczędzają ani króla, ani magnatów, ani obyczajów politycznych, gd zie .,król takim, co obieca, rad da”, a w istocic rzeczy ,przeda”, zaś ksiçża popierający Zygmunta III, zwłaszcza jezuici opowiadający się za wzmocnieniem whadzy monarchy, „broją”, a więc nie popieraja postulatów szlachty rokoszańskie Jezuici „cicho praktykują”, wspierając whadcę, a w istocie „knuja”, a zlotousty kaznodzicja Piotr Skarga w swych nasyconych retoryką kazaniach glośno agituje szlachtę za pozostaniem przy królı, wykonując „zlą robotę”. Edho zaciekle zwalcza obóz królewski, utwór jest pelen jadu i nienawiści autora do polityków i szlachty skupionej wokól króla. Próbę scharakteryzowania galerii polskich polityków, z monarchą na czele, autor wykonał dobrze. Konsekwentnie utrzymywal się w roli satyryka swoich czasów, zaten mial prawo do stosowani: liperbolizacji i przejaskrawień. Jego inwektywy kierowane pod adresem polityków, choć formulowane tendencyjnie, odzwierciedlaja poglądy polityczne szlachty rokoszowej. Wiersz ma zatem duzą wartość dokmmentarmą.

Obok polskiego Edha rokosaniskingo manny, inne - lacińskic Echoo rokoszu. Wodróżnieniu od poprzedzającego, jest to przykład pierwszego rodzaju echa. Pochodzi ono, jak i weześniej omawiany utwór, z okresu sandomierskiego, i można je potrak tować jako ciekawe jego uzupehnienie:

\section{Echo o rokoszu}

1. [Na I Iicronima (rostomskicgo, wojewodę poznaństicgo i Zygmunta Myszkowskiego, matrsatka wiclkiego koronnegol.

Quid sic plangis angusto deicotus amimo? - Imo

Pone metum, esto vil labora extremis - Remis.

Mea furto polluta tenera indoles - Oles.

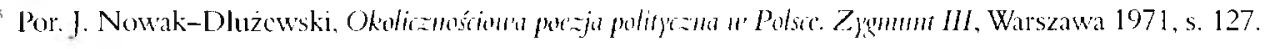


Nam rege sub . Augusto ukradtem zaponç - Onę.

I obrus a Bandisa przede mną rzezano - Ano.

I żydowi dworskiemu ukradłem sobola - Ola.

I lańcuch takje zloty w Pradze Tanowskicmu - Jemu.

Et tu licet proditor, provice has curns - Duras.

Arma tenta potius nec smmptus denega - Nega.

Milites acre para, ego mat tecum - Ecam.

Miles acra semuitur munc pandas aquilas - Illas.

Fata viam pracbebunt, Austria in'abit - Abit.

In mobiles at Mus canus iram innget? - Niet.

Rokosz est res horrda, in dubio tita - Ita.

Possmm in Italia esse sine Pama - Arma.

Ego multos banditos noti ex Italis - Talis.

In hoc mihi spes wha restat et iuramen - Amen.

2. Na druģicgo [Myszkowskicgo]

Ergo in Italiam, proh dolor! mardio? - Io.

Ibo exul, profugus aum meis aqullis? - Illis.

Cum stemmate alio sub sole quaesio? - Ito.

Ergo me accipiet gremio Mantua? - An tum.

Et me ad pobratinos conferam Gonzagas? - Agas.

Prole dolor; qui ingenti floveluam applausu? - Ausu.

Et late Italico me efferabam fastu? - Astu.

In patria exules titulos dum quatero. - Erro.

$O$, cui relinquam aedes marmoreas - Eas.

O, domus, o patria Xiqz, et Pincolia - I ia!

O, Formosa mi Licon, quam o, muestmosus - Ostus.

Adulter suae uxoris, dilexi uxorem - O rem!

Ingalen dam thalamum incestu polluo - Lan.

Idem stuasi principi, tersus Sodomita - Ita.

Promubus paranimphis enendidi Prassiann - Iam.

Et anctor fiu regi violare fidem - Idcm.

Adulationibus et modo pernili - I ili.

Respublica munc fremit, poenas pult sumere - Mere.

Ah, demens, o patria, cogor exwlare - Lare'.

Echo to poświęcone jest calkowicie tylko dwu dzialaczom partii dworskiej: wojewodzie Ilieronimowi Gostomskiemu i Zygmuntowi Myszkowskiemu, zaprezentowanym w osobliwej roli przyszłych emigrantów politycznych po zwycięskim objęciu przez rokoszan rządów

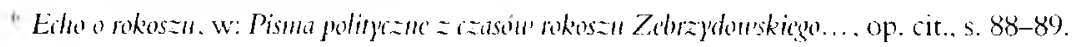


w kraju ${ }^{7}$. Myszkowski jest szczególnie predysponowany do swej emigranckicj przyszlości. Przecież to margrabia Gonzaga, którego przyjmie jako swego Mantua, bo tam uzyskal herby i tytuly. W kraju zasłużył się najwiçcej Zygmuutowi III, knując jego małzeństwo z siostrą zmarkej Anny, sam zaś, prywatnic - mąż dwu rodzonych sióstr Boguszówien - ma jedno zmartwienie:
O, ani relinquam acdes marmoreas? - Eas.
O, dommes, o patria Xią et Pincovia! - I ia

Siedziba margrabicgo - Książ Wielki - który nawet dziś robi wrażenie swym renesansowym zankiem Mirowem, położonym na lesistym wzgórzu, dziełem architekta Zygmunta Augusta, Batorego i Zygnumnta III, Santi Guccicgo, twórcy pięknej kaplicy św. Anny położonej na górze nad Piníczowcm, nic mówiąc już o zanku pińczowskim i pińczowskim Mirowie, bogato wyposażonych siedzibach Gonzagów Myszkowskich — godzien był w rzeczywistości opłakiwania, w wypadku gdyby trzeba mu powiedzieć „żegnaj” i udać się na emigrację.

Na uwage zasługuje również część Edha o rokoszu poświęcona Gostomskiemu, a to dziçki polskim wtrętom, zawierającym skandaliczną kronikę wydarzeń z życia wojewody poznańskiego. Zarzuty nawet dziś robią wielkie wrażenie, bo trudnym do pojęcia jest, że wojewoda poznański do tego stopnia nie szanowal się, iz kradl cenne przednioty, i to wielokrotnie. Okryl się wielką niestawą, stracil u ludzi poważanie, piętnowano go w towarzystwie. Byla to praktyka dość powszechna, zostala wzmiankowana w Satyrze Kochanowskiego:

[...] Cnota i przystojenístwo do kąta się tuli;

A ich plac nicwstydliwa potwarz zastąpila.

Na co trzeba statutów i rzeczniliów sila.

A onych jakobyśny tu przypomniéc micli,

Którzy ani sieść za stół z podejżrzanym chcicli?

Obrus przed nim rzezali, talerz nożmi kłoli,

Jeśli nie chcial ustapić, musial po niewoli".

Jeśli przy stole usiadl czlowiek podejrzany o przestępstwo, współbiesiadnicy protestowali przeciw jego towarzystwu w ten sposób, że bili w talerze nożani i przecinali przed nim obrus. W ten sposób napiętnowany dyfamator był zmuszony opuścić gardzących nim ludzi.

Autor Echa... zlośliwie zauważa, że Gostomski, podobnie jak Myszkowski, był bywalcem Italii, nic więc dziwnego, zo po zwycięstwic rokoszan wojewoda jako przyszly emigrant tam wlaśnie się znajdzie ${ }^{\prime \prime !}$.

\footnotetext{
Por. J. Nowak-Dluzicwski. op. cit. s. 129.

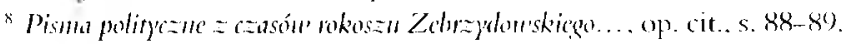

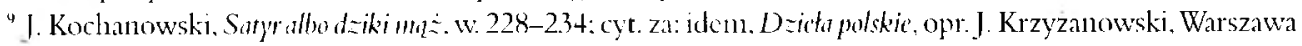
1980, s. 6.3-64.

"Por. J. Nowak-Dlużewski. op. cit., s. 130.
} 
Innym utworem należącym do pierwszego rodzaju echa jest Edho żafobne" . Utwór ten, nieznanego autorstwa, jest apelem do walki o podupadającą ojczyznç:

Kędy twoja ozdoba, Polsko utrapiona? - Ona.

Kędy zgoda, gdzie sława? Wieleć nic dostaje - Taje.

Kędy szczęście życzliwe, co nas cieszyć zwykło? - Znikło.

Litujcie, wdziçcznc Muzy, dziś ludzkiej utraty - A ty?

Oblewa się dziś lzami sławna Sklawonija - l ja.

Ginie mila swoboda, która byla w ale - Ale.

To wszystko prze niezgodę, ta tego przyczyną - Iną.

Kto przyczyną rozterków, snać wolność skazona? - Ona.

Wnętrzna wojna upadkiem grozi utrapionym - Onym.

Pogubila niezgoda wiele państw w zlej sprawie - Prawie.

Tu się wadzą, a braciej w Podolu nabito - I to.

Dokazuja nad niemi Getae Samactici - Ty cyt!

Gdzie one zlote lata, próżne złcj przygody? - Gody?

Kędy szczęśni hetmani? Powicdz kto, możeszli - Zeszli.

Prędka upadku droga, gdzie kto nie wspomoze - Może.

By wiedzieć, jako długo czas swoim obrotem - O tenl.

Karać nas wszytkich będzie nieżycznym klopotem? - Potem ${ }^{1 ?}$.

Widać, że przez nieznanego nam autora przemawia zal i poczucie krzywdy wywołane rozgrywającymi się wydarzeniami politycznymi. Utwór, zgodnie z sugestią znaj̣dującą się już w tytule, ma charakter zalobny. Wynika to z oplakiwania utraconej wolności. Rzeczywistość budzi niepokój. Rzeczpospolita zmierza w niedobryın kierunku, źle się zaczyna dziać w państwie polskim, przepadly zgoda i slawa, ,ginie mila swoboda” — "zlota wolnośc” szlachecka. Autor, podobnie jak wcześniej Jan Kochanowski w Pieśni piątej „ksiąg wtórych” O spustoszeniu Podola, krytykuje bezmyślność i krótkowzroczność Polaków. Powszechnie bowiem wiadomo, ze wszelkie spory, niezgody i wojny prowadzą do upadku miast, a nawet państw. Dlaczego więc Polacy, niezınuszeni do wojny, sami ją rozpętują ze szkodą dla swojej ojczyzny? (.Wewnętrzna wojna upadkien grozi utrapionym - Onym”). Zatem rokusz, wojna domowa jest wielkim zlem, a sami rodacy tę sytuację wyreżyserowali. Dla autora Echa żatobnego nie do pomyślenia jest taka lekkomyślność. Naród zajęty politycznymi sporami nie zwraca uwagi na ciągle podjazdy Tatarów i wojsk tureckich na Podole. Poeta, mając świadomość, jak daleko posunęla się Rzeczpospolita w upadku swej potęgi, pyta: „Gdzie one zlote lata, próżne zlej przygody?” Odpowiedź echa jest bardzo wymowna: piękne, wielkie czasy Rzeczypospolitej przeminęly jak "gody”, święta Bożego Narodzenia. Polska nie ma już wybitnych hetmanów — wybitnych indywidualıości, cieszących siç powszechnym poważaniem, porywających lu-

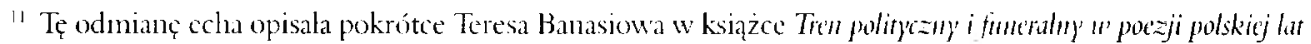
1580-16.30, Katowice 1997. s. 45.

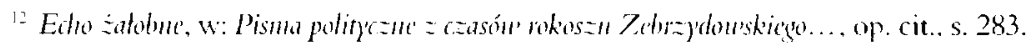


dzi do walki. By taki stan rzeczy nie skończyl siç dla kraju tak tragicznnie, jak zapowiada to Odpran'a postón' greckich Kochanowskiego, czyli utratą państwowości i wielką, haniebną klęską, należy juz teraz dostrzegać błędy w postępowaniu, nie kicrować się prywatą, a myśleć perspektywicznie o przyszłości kraju i przcjmować się przede wszystkim jeģo losem, na końcu zaś whasnymi prywatnymi potrzebani.

Z dokonanego przeglądı utworów o tematyce rokoszowej wynika, że w zasadzie studia nad echem jako gatunkiem literackim zaledwie się rozpoczęły, a ich plon naukowy prezentuje się nad wyraz skromnie, również pod względem edytorskim. Wielkim utrudnieniem dla badaczy jest bardzo trudny dostęp do tekstów poukrywanych w rękopisach i starych drukach. Pilną potrzebą jest zgromadzenie wszystkich dostępnych tekstów, wnikliwa ich klasyfikacja i wszechstronna, dogłębna ich analiza i interpretacja oraz nowoczesna, pehna edycja krytycz11a. Należy żywić nadzieję, że niniejsza praca jest pierwszym krokiem w tym kierunku, że daje właściwe rozeznanie co docech gatunkowych badanych tekstów, ich klasyfikacji i wartości artystycznej, oraz ze daje dubre wyobrazenic o ich tematyce.

Zaprezentowane utwory wywołuja pytanie: w jaki sposób struktura echa określa wirtualnego odbiorcę? Ma on być aktywnym czytelnikiem. Zapewne autorzy liczyli się z zamówienicm społecznym na tego typu wiersze, które spełnialy zarówno zadania ludyczne, jak i propagandowc, a ściśle biorąc aspekt ludyczny pozostawał na usługach polityki. W tym wypadkı ważna jest wiedza o tym, jakie stanowisko polityczne prezentowat odbiorca, z którym autor prowadził swoisty dyskurs. Badacz musi dotrzeć do konwencji literackiej, w której echo się kształtowało, aby ustalić, do jakiego stopnia ta konwencja była przez odbiorcę wierszy znana i akceptowana, jakic elementy tej konwencji miały dla odbiorcy znaczenie zasadnicze, a jakie drugorzędne.

Rozpoznanie konwencji jest warnnkiem wstępnym zrozunnienia, czy tez [...] właściwej recepcji utworu. Dzieło, realizując zasady dancj konwencji, projektuje i narzuca odbiorcy pewnego typu zachowania w stosunku do siebie, które umożliwiaja zrozumienie utworu. Przez rozumienie pojmuję tutaj nie tylko umiejęctności odczytania whaściwych znaczení słów użytych w tekście, mam na uwadze przede wszystkim uchwycenie regut ich wiązania oraz odnicsicnia do ogólnych zasad, wedlug których wypowiedź została skonstruowana ${ }^{13}$.

Odbiór echa przez czytelnika ma być czynny, aktywny, bez niedomówień. Dodatkowym czynnikiem przykuwającym uwage ma być oryginalny ksztalt artystyczny, bardzo wyszukana forma, jak się udało wskazać, występująca w poezji z początku XVII wieku w trzech odmianach.

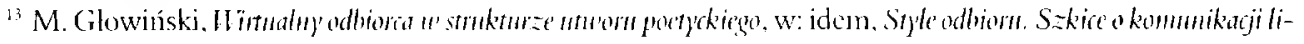
terackiej, Kraków 1977, s. 75-76.
} 
Bez wątpienia sq to utwory konceptystyczne ${ }^{1+}$. Echo to gatunek bardzo wyrafinowany pod względem artystycznym. Analizowane utwory potwierdzają tę konstatację. Ambicje ich twórców są bardzo duże, znakomicie opanowali oni trudną formę wypowiedzi poetyckiej, koncept dziala wielokiermukowo. Ważną decyzją warsztatową była koegzystencja „ja” lirycznego z ,ty" lirycznyın, bo odpowiedzi echa należy uznać za ckwiwalent owego „ty”. Ciekawym zabiegiem psycholingwistycznym jest sama formula echa. Efekt akustyczny odbicia i powtarzania dźwięku jest nie tyle formą gry z czytelnikiem, co raczej sposobem manipulacji nim. Byl to niezwykle ciekawy, ,zabieg medialny”: nie tylko przekazywal gotową spreparowaną informację, ale poprzez podświadomość miał kształtować odpowiednie postawy obywatelskie, a jeszcze bardziej polityczne. Przekazywane przez nadawcę wiadomości, odbijające siç echem, nie byly juz tylko opiniąjedncj osoby, ale catej rzeszy odbiorców. Przy pomocy tego chwytu dźwiękowego można było uzyskać złudzenie, że jest to opinia popularna, którą warto popierać. Zabieg ten jest tym bardziej istotny, że w ferworze walk politycznych zawsze chodzi o bezkompromisowe podporządkowanic pewnej rzeszy ludzi - a to podporządkowanie

tylko do pewnego stopnia da się wyprowadzić z przekonań ludzkich. Najważnicjsze jest jednak to, by jednosthi uwierzyly, że określone dzialanie zmierza w kierminu realizacji ich wlasnego dobral ${ }^{15}-$

a przecież w takim celu pisano utwory polityczne, w tym echa.

Celem analizowanych utworów była polemika ich autorów z poglądami antagonistów, czasem nawet wyszydzenie przeciwnika, zlośliwe akcentowanie pewnych zjawisk czy postaw przeciwników, hiperbolizacja wad, poglądów. Można te echa uznać za namiastkẹ publicystyki politycznej, bo polemika odbywa się na terenie poezji okolicznościowej. Są to krótkie wiersze, teksty łatwe do zapamiętania i hatwe do rozpowszechniania. Są ambitne pod względem artystycznym, spelniają horacjański postulat, że poezja powinna uczyć i dostarczać przyjemności estetycznej (doceré et delectare). Mamy do czynienia z poezją kunsztowna, która bierze na sicbie zadania ludycznc. Wirtuozeria warsztatowa ma zwracać uwagę czytelnika, zintensyfikować skuteczność oddziaływania na niego. Odbiorca ma reagować zarówno na dominantę wywodu utworu okolicznościowego, jak i na wyszukaną formę literacką. W intencji twórcy wierszy okolicznościowych czytelnik powinien wybierać zawarte w utworze idec zgodnie z zamiarem autora, dać się przekonać do jego poglądów politycznych. W zakresie stylu autorzy piszący echa odznaczali się wielką inwencją twórczą. Wiersze te charakteryzują siç ciçtością repliki pozostającej na usługach polemiki politycznej, wspomaganej często przez zlośliwy żart. Poeci wykorzystuja zabawy, gry slowne, makaronizowanie, aby wzmocnić uprawianą w wierszu propagandę polityczną. Ostra polemika występuje niejednokrotnie w polączeniu

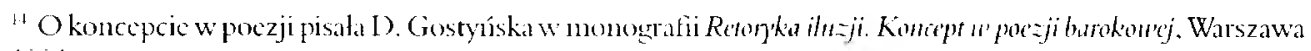
1991 .

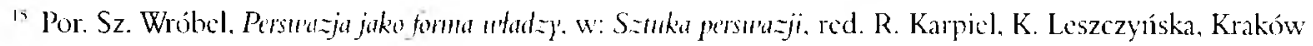
2004 . s. 33 .
} 
z satyra". Zwalcza ona przeciwników politycznych, kompronituje ich, ich poglądy, ich program. Pojawiają się akcenty patriotyczno-krytyczne: zjednej strony milość do ojczyzny i troska o jej dobro, z drugicj świadoność, jak licznymi wadami odznacza sę życie społeczno-polityczne Rzeczypospolitej. Widać w każdym echu silne zanngażowanie emocjonalıe podmiotu, jego doskonalą znajomość real lów politycznych (walki stronnictw regalistów i rokoszan).

Echo jako stosunkowo nowy gatunck w poezji XVII wicku oddat duze uslugi okolicznościowej poezji politycznej doby rokoszu Zebrzydowskiego jako znakomicie oddający atmosferę napięć politycznych, atmosferę klótni raczej niż dialogıı.

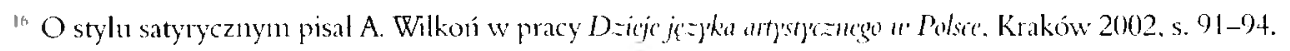

